\title{
Clinical leishmaniosis in a captive Eurasian otter (Lutra lutra) in Spain: a case report
}

\author{
Ana Cantos-Barreda ${ }^{1}$, Ricardo Navarro ${ }^{2,3}$, Luis Pardo-Marín², Silvia Martínez-Subiela ${ }^{2}$, Elena Ortega ${ }^{3}$, José J. Cerón²,
} Fernando Tecles ${ }^{2}$ and Damián Escribano ${ }^{2,4^{*}}$ (D)

\begin{abstract}
Background: Captive and free-ranging wild mammals have been recognized as potential reservoirs of Leishmania infantum infection. The aim of this study was to describe the first clinical case of leishmaniosis in the Eurasian otter.

Case presentation: A case of clinical leishmaniosis is reported in a 4-year-old male Eurasian otter housed at a wildlife park (Murcia, South Eastern Spain). The Eurasian otter showed bilateral epistaxis, anorexia, apathy, and weight loss. A complete blood cell count and biochemical analyses revealed hyperproteinemia, hyperglobulinemia, decreases of paraoxonase-1, increases of haptoglobin and ferritin, and proteinuria. Bilateral nephropathy with hydronephrosis, mesenteric lymphadenomegaly, and ascites were also observed. L. infantum infection was confirmed by microscopy (amastigotes were detected in macrophages from spleen aspirate), molecular diagnosis (L. infantum DNA was detected by real-time polymerase chain reaction), and serology (anti-Leishmania lgG2 antibodies were detected by time-resolved immunofluorometry). The animal was treated with allopurinol for 3 months and gained weight, the epistaxis disappeared, and the ferritin concentration decreased.

Conclusions: This is the first report of clinical leishmaniosis in the Eurasian otter. Our results suggest that Eurasian otters are susceptible to infection with $L$. infantum and can develop clinical leishmaniosis in endemic areas.
\end{abstract}

Keywords: Eurasian otter, Leishmania infantum, Leishmaniosis, Lutra lutra, Natural infection

\section{Background}

Leishmaniosis is a zoonotic disease caused by the protozoan parasite Leishmania infantum in the Mediterranean area, affecting a wide range of mammals, including humans [1]. Domestic dogs act as the main reservoir, and Phlebotomus perniciosus is the main vector for $L$. infantum in the South East of Spain, an area in which this parasite is endemic [2]. Recently, L. infantum infection has been described in mustelids such as the domestic ferret (Mustela putorius furo) in Spain [3], and free-ranging badgers (Meles

\footnotetext{
* Correspondence: det20165@um.es

${ }^{2}$ Interdisciplinary Laboratory of Clinical Analysis, Interlab-UMU, Regional Campus of International Excellence "Campus Mare Nostrum", University of Murcia, 30100 Espinardo, Murcia, Spain

${ }^{4}$ Department of Animal Production, Regional Campus of International Excellence "Campus Mare Nostrum", University of Murcia, 30100 Espinardo, Murcia, Spain

Full list of author information is available at the end of the article
}

meles) in Italy [4]. L. infantum infection in the Eurasian otter (Lutra lutra) was detected for the first time in wild otters from Asturias (North Western Spain) by Oleaga et al. [5]. However, as far as we are aware, no data exist about clinical cases of leishmaniosis in this mustelid, which is a "near threatened" and fully-protected species. The aim of this report was to describe the first clinical case of leishmaniosis in the Eurasian otter.

\section{Case presentation}

A 4-year-old male Eurasian otter born in 2015 in the 'Sendaviva, Natural Park of Navarra' $\left(42^{\circ} 11^{\prime} 31^{\prime \prime} \mathrm{N}, 1^{\circ} 34^{\prime}\right.$ 33"O) (North Eastern Spain) was transferred to the 'Terra Natura' wildlife park (South Eastern Spain) in 2017. The 'Terra Natura' wildlife park is located in the periurban surroundings of Murcia city $\left(38^{\circ} 00^{\prime} 40^{\prime \prime} \mathrm{N}\right.$, $\left.1^{\circ} 09^{\prime} 54^{\prime \prime} \mathrm{O}\right)$. The otter enclosure consisted of an area

(c) The Author(s). 2020 Open Access This article is licensed under a Creative Commons Attribution 4.0 International License which permits use, sharing, adaptation, distribution and reproduction in any medium or format, as long as you give appropriate credit to the original author(s) and the source, provide a link to the Creative Commons licence, and indicate if changes were made. The images or other third party material in this article are included in the article's Creative Commons licence, unless indicated otherwise in a credit line to the material. If material is not included in the article's Creative Commons licence and your intended use is not permitted by statutory regulation or exceeds the permitted use, you will need to obtain permission directly from the copyright holder. To view a copy of this licence, visit http://creativecommons.org/licenses/by/4.0/ The Creative Commons Public Domain Dedication waiver (http://creativecommons.org/publicdomain/zero/1.0/) applies to the data made available in this article, unless otherwise stated in a credit line to the data. 
with free-access shelters and a pond containing 4 animals of this species ( 2 male and 2 female). No pouron anti-sandfly insecticide was applied to the otters. In August 2019 the animal presented bilateral epistaxis, anorexia, apathy, and weight loss (Fig. 1). The animal was sedated prior to manipulation with medetomidine $(0.2 \mathrm{mg} / \mathrm{kg} / \mathrm{i} . \mathrm{m}$.) and ketamine $(20 \mathrm{mg} / \mathrm{kg} / \mathrm{i} . \mathrm{m}$.). Whole blood was taken by venipuncture of the cephalic vein, drained into a $1 \mathrm{ml}$ tube coated with ethylenediaminetetraacetic acid (EDTA) and a $1 \mathrm{ml}$ tube without anticoagulant for a complete blood cell count (CBC) and biochemical analyses, respectively. The $\mathrm{CBC}$ was performed in a blood cell counter (ADVIA 120 Hematology System, Siemens, Italy), and the biochemical analyses were performed in an automated biochemistry analyzer (Olympus AU600 Automatic Chemistry Analyzer, Olympus Europe $\mathrm{GmbH}$, Hamburg, Germany). In addition, urine was taken by Ultrasound Guided Cystocentesis for urinalysis. An echography study of the heart and abdominal organs including kidney, spleen, liver, gallbladder, pancreas, and digestive system, was performed. As the biochemical and echographic results were compatible with the clinical leishmaniosis, serological and molecular tests were performed to confirm the presence of the infection.

The presence of anti-Leishmania IgG2 antibodies was evaluated in the serum of the otter by a time-resolved immunofluorometric assay (TR-IFMA) performed as described by Cantos-Barreda et al. [6]. In order to test that the TR-IFMA assay validated for dog serum can be applied to otter serum, a Western blot analysis was carried out. The Western blot was performed in sera from the otter with leishmaniosis-compatible signs, and

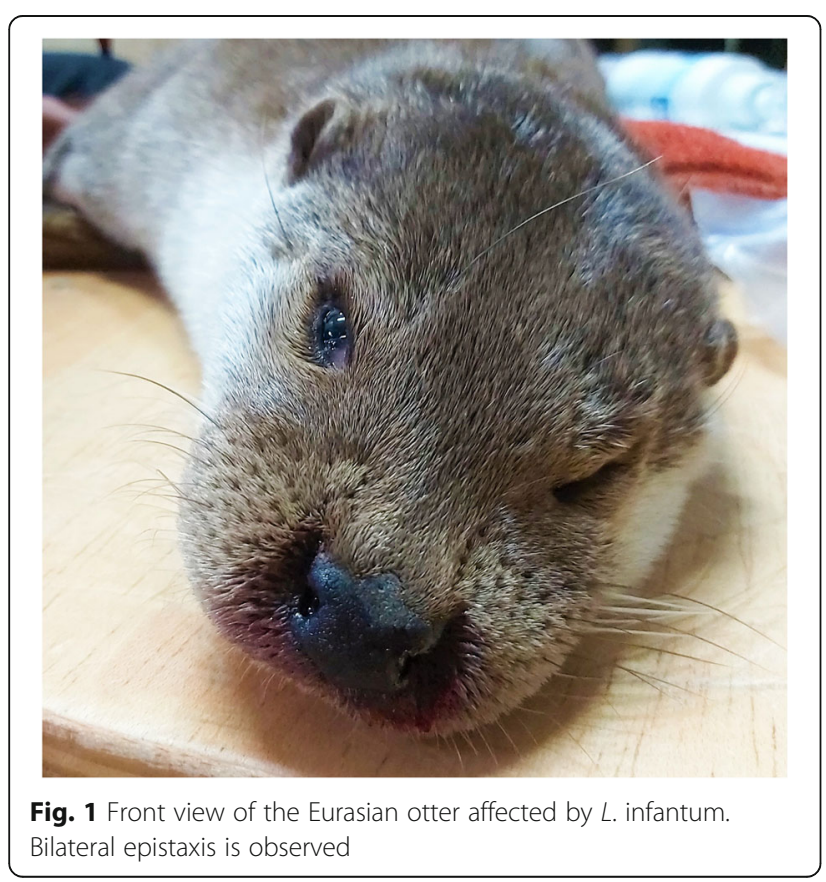

from a Leishmania-seropositive dog by TR-IFMA. The sera (1:2000 dilution) were separated under reducing conditions on mini polyacrylamide gels $(0.1 \%$ sodium dodecyl sulfate (SDS), $12 \%$ resolving gel, and $4 \%$ stacker gel). The resolved proteins were electrophoretically transferred to a nitrocellulose sheet (Bio-Rad, USA) and placed in a ROTIL Lumin substrate (Carl Roth, Germany) to block for $2 \mathrm{~h}$ at room temperature. Sheep polyclonal antibody anti-dog IgG2 (AHP498; Bio-Rad, USA) at 1: 1000 dilution was used as the primary antibody, while rabbit anti-sheep IgG horseradish peroxidase (HRP)conjugated (SAB3700702; Sigma-Aldrich, USA) at 1: 1000 dilution was used as the secondary antibody to detect the bound primary antibody. Signal detection was done using a Pierce ECL2 kit (Pierce, Thermo Fisher Scientific, USA) and was digitalized in the Typhoon 9410 scanner (GE Healthcare, USA). A band of approximately $150 \mathrm{kDa}$ was observed in the otter sample as well as in the canine sample (see Fig. 2 and Additional file 1). These findings corroborated that the TR-IFMA assay using sheep anti-dog IgG2 was able to detect the IgG2 of the otter. The TR-IFMA assay consisted of a noncompetitive indirect method based on biotinylated K39 recombinant antigen as a capture reagent, and anti-dog IgG2 polyclonal antibody (Sheep anti-Dog IgG2, Bio-Rad, USA) $\mathrm{Eu}^{3+}$-labelled as a detector. The test included serum from a sick Leishmania-seropositive dog as a positive control, and serum from a healthy Leishmania-seronegative $\mathrm{dog}$ as a negative control. The analysis was performed in a multilabel counter (VICTOR ${ }^{2}$ 1420, PerkinElmer Life and Analytical Sciences, Turku, Finland). Results were expressed as Units of fluorometry for Leishmania (UFL). The cut-off was set at 22 UFL. Also, an enzyme-linked immunosorbent assay (ELISA) (Leiscan Leishmania ELISA Test, Esteve Veterinaria, Laboratorios Dr. Esteve SA, Barcelona, Spain) detecting specific IgG antibodies against Leishmania spp. was performed, according to manufacturer's instructions. Sera samples were diluted 1:20 and the results were expressed as sample-to-positive $(\mathrm{S} / \mathrm{P})$ ratio, calculated by optical density (OD) sample/OD low positive control. Values of S/P ratio above 1.1 were considered positives.

The presence of Leishmania spp. DNA in whole blood and bone marrow was evaluated by amplification of the kinetoplast DNA sequence of Leishmania spp. using an rtPCR with primers and probes previously described [7]. Bone marrow was taken through fine-needle aspiration from the costochondral union, and drained into a $1 \mathrm{ml}$ tube coated with EDTA. DNA was extracted using the High Pure PCR Template Preparation Kit (Roche, Germany), following the manufacturer's instructions. The rtPCR was performed in the QuantStudio 5 Real-Time PCR System (Applied Biosystems, Foster City, CA, U.S.A.). The internal control TaqMan Exogenous Internal 


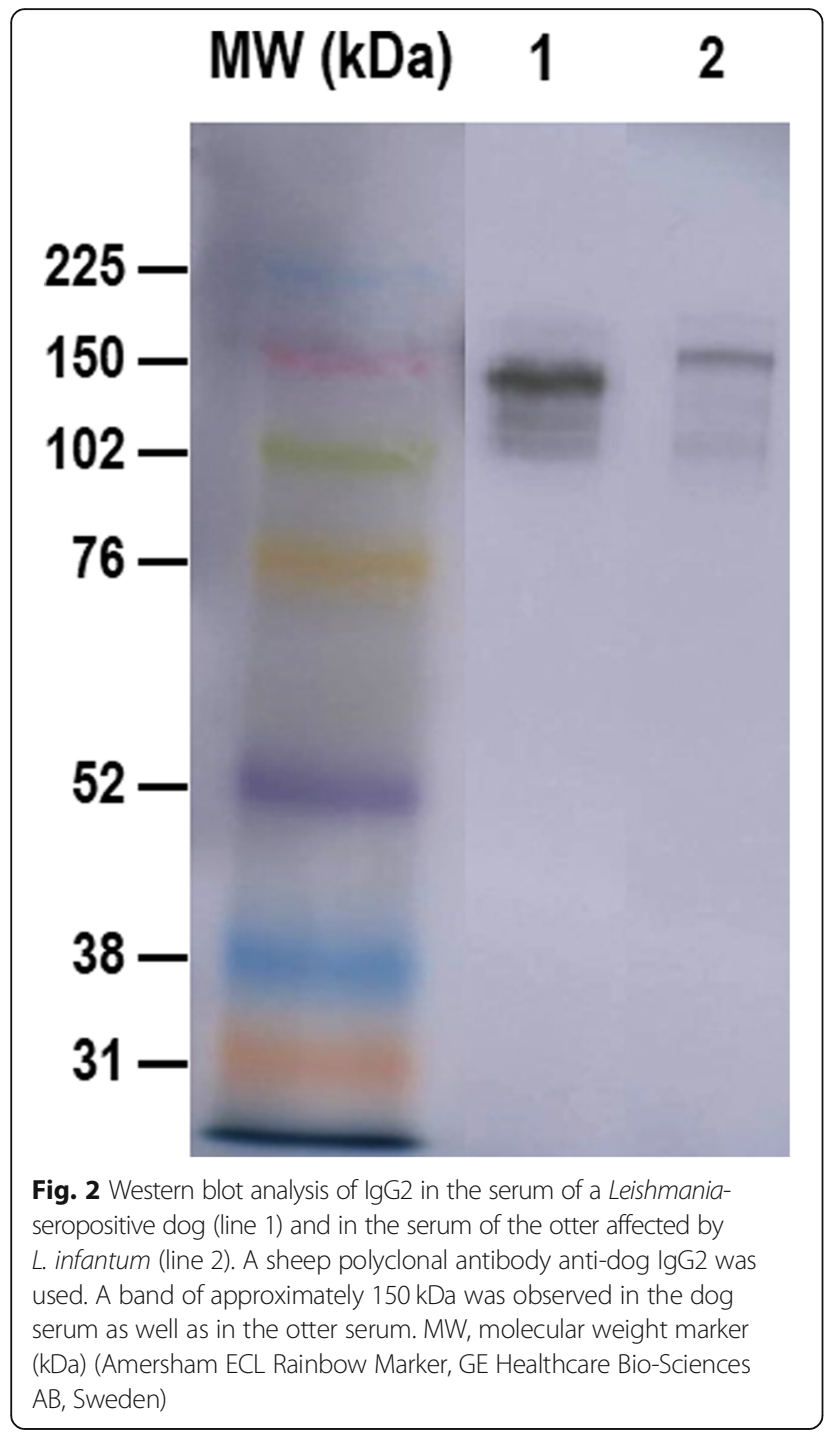

Positive Control Reagents (VIC Probe) (Exo IPC) (Applied Biosystems, CA, U.S.A.) was included. The rtPCR was performed in a final volume of $20 \mu \mathrm{L}$, including $1 \times$ iTaq Universal Probes Supermix (Bio-Rad, CA, U.S.A), $900 \mathrm{nM}$ of each primer, $200 \mathrm{nM}$ of TaqMan probe, 1× Exo IPC Mix, $1 \times$ Exo IPC DNA, and $50 \mathrm{ng}$ of DNA from each sample. The cycling parameters were: $50^{\circ} \mathrm{C}$ for $30 \mathrm{~s}, 95^{\circ} \mathrm{C}$ for 10 min, 45 cycles at $94{ }^{\circ} \mathrm{C}$ for $30 \mathrm{~s}$, and $55^{\circ} \mathrm{C}$ for $1 \mathrm{~min}$. Each amplification run included positive and negative controls, and each measurement was accomplished in triplicate. For the Leishmania species identification, the PCR products from the positive samples were purified using the High Pure PCR Product Purification Kit (Roche, Germany) and submitted for sequencing at the Section of Molecular Biology, University of Murcia. The sequences obtained were compared to those available in GenBank.

Additionally, as negative control, the same analyses were performed on a 3-year-old female Eurasian otter from the same wildlife park with no clinical signs compatible with leishmaniosis.

All the results appear in Table 1. The occurrence of leishmaniosis was confirmed, and specific treatment was administered (allopurinol $15 \mathrm{mg} / \mathrm{kg} / 24 \mathrm{~h} / \mathrm{p}$.o.). Treatment monitoring was performed, in November 2019, after 3 months of treatment. Bilateral nephropathy with hydronephrosis, mesenteric lymphadenomegaly, and ascites were observed. The $\mathrm{CBC}$ revealed decreases in white blood cells, and decreases in platelets in the Leishmania-positive otter. The serum biochemical profile for the Leishmania-positive otter showed hyperproteinemia, hyperglobulinemia, decreases of PON-1, and increases of haptoglobin and ferritin. The urinalysis revealed proteinuria and decreases in the osmolarity and specific gravity. The presence of anti-Leishmania IgG2 antibodies, and a positive result by rtPCR in terms of whole blood and bone marrow, was observed for the Leishmania-positive otter. The sequencing of positive samples confirmed the identification of L. infantum. The amplified sequence exhibited $100 \%$ similarity with a $L$. infantum reference sequence. In addition, oval microorganisms with an eccentric nucleus compatible with Leishmania spp. amastigotes were observed in the cytology of the spleen (Fig. 3).

\section{Discussion and conclusions}

To the best of the authors' knowledge, this is the first report describing a case of clinical leishmaniosis in the Eurasian otter. This species has been reported as being susceptible to Leishmania infection, as DNA from this parasite was detected in 7 out of 10 wild healthy Eurasian otters from North Western Spain, a non-endemic area for canine leishmaniosis (CanL) [5]. Santoro et al. [9] confirmed Ehrlichia canis and Rickettsia spp. infection in the South Italian population of Eurasian otters, and Chadwick et al. [10] indicated that Toxoplasma gondii infection is common in Eurasian otters in the United Kingdom. In addition, it was reported that this species may occasionally be infected with Dirofilaria immitis [11].

The diagnosis of clinical leishmaniosis described in this report was demonstrated by serological and molecular results, similar to a previous report describing the first case of $L$. infantum infection in a domestic ferret (Mustela putorius furo) in Spain [3]. In dogs, the serum total levels of anti-Leishmania IgG, IgG1 and IgG2 are elevated during the active phase of Leishmania infection, the IgG2 being the predominant subclass $[12,13]$. At this moment, elevated levels of anti-Leishmania IgG2 in serum were found, as previously reported in dogs with clinical leishmaniosis using TR-IFMA [6]. High levels of anti-Leishmania IgG were also detected in the serum from the sick otter by the commercial ELIS A. So, both serological results (TR-IFMA and ELISA) were 
Table 1 Clinical signs, analytical findings, cytology, serology, and rtPCR results recorded in the case of the two Eurasian otters

\begin{tabular}{|c|c|c|c|}
\hline Animal description & Male, 4 years & & $\begin{array}{l}\text { Female, } 3 \text { years } \\
\text { (negative control) }\end{array}$ \\
\hline Dates of screening & August 2019 (diagnosis) & $\begin{array}{l}\text { November } 2019 \\
\text { (treatment) }\end{array}$ & November 2019 \\
\hline Clinical signs & $\begin{array}{l}\text { Bilateral epistaxis, anorexia, apathy, weight loss, } \\
\text { bilateral nephropathy with hydronephrosis, } \\
\text { mesenteric lymphadenomegaly, ascites }\end{array}$ & Light hydronephrosis & No signs \\
\hline \multicolumn{4}{|l|}{ CBC (reference values) ${ }^{a}$} \\
\hline White blood cells $\left(3.1-19.2 \times 10^{3} / \mathrm{mm}^{3}\right)$ & 4.5 & 3 & 4.6 \\
\hline Platelets $\left(178-777 \times 10^{3} / \mathrm{mm}^{3}\right)$ & 156 & 296 & nd \\
\hline \multicolumn{4}{|l|}{ BP (reference values) } \\
\hline Total proteins $(6-7.7 \mathrm{~g} / \mathrm{dL})^{a}$ & 10.4 & 12.2 & 6.7 \\
\hline Albumin $(1.25-3.6 \mathrm{~g} / \mathrm{dL})^{a}$ & 2.4 & 2.1 & 3.6 \\
\hline Globulin $(2.7-4.8 \mathrm{~g} / \mathrm{dL})^{\mathrm{a}}$ & 8 & 10 & 3.1 \\
\hline PON-1 $(3-4.3 \mathrm{IU} / \mathrm{mL})^{\mathrm{b}}$ & 2.1 & 2.5 & 6.5 \\
\hline Haptoglobin $(<3 \mathrm{~g} / \mathrm{L})^{\mathrm{b}}$ & 3.3 & 1.4 & 0.1 \\
\hline $\operatorname{CRP}(<12 \mu \mathrm{g} / \mathrm{mL})^{\mathrm{b}}$ & 3.7 & 4 & 6.7 \\
\hline Ferritin $(60-190 \mu \mathrm{g} / \mathrm{L})^{\mathrm{b}}$ & 2820 & 266 & 111 \\
\hline Blood urea nitrogen $(17.3-68.1 \mathrm{mg} / \mathrm{dL})^{\mathrm{a}}$ & 37.1 & nd & nd \\
\hline Serum creatinine $(0.7-1 \mathrm{mg} / \mathrm{dL})^{a}$ & 0.7 & nd & nd \\
\hline \multicolumn{4}{|l|}{ Urynalisis (reference values) $^{b}$} \\
\hline Urine protein/creatinine $(\mathrm{UPC})$ ratio $(<0.2)$ & 3 & nd & nd \\
\hline Urine osmolarity (> 500 mOsm/L) & 363 & nd & nd \\
\hline Urine specific gravity (1.015-1.045) & 1.012 & nd & nd \\
\hline Serology results by TR-IFMA ( $<22$ UFL) & 266.6 & 229.4 & 4.84 \\
\hline Serology results by ELISA (< 1.1 S/P ratio) & 4.9 & nd & 0.3 \\
\hline Spleen cytology (microscopy) & $\begin{array}{l}\text { Presence of Leishmania } \\
\text { spp. amastigotes }\end{array}$ & $\begin{array}{l}\text { Presence of Leishmania } \\
\text { spp. amastigotes }\end{array}$ & nd \\
\hline \multicolumn{4}{|l|}{ RtPCR results (parasites/ng DNA $\times 10^{3}$ ) } \\
\hline Peripheral blood & 13.89 & nd & NAC \\
\hline Bone marrow & 222.81 & nd & nd \\
\hline
\end{tabular}

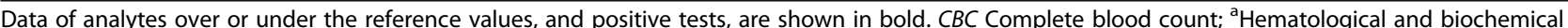
Eurasian otter reference values [8]; BP Biochemical profile; 'Interlab-UMU biochemical canine reference values; PON-1 Paraoxonase-1; CRP C-reactive protein; TR-IFMA Time-resolved immunofluorometric assay; UFL Units of fluorometry for Leishmania; ELISA Enzyme-linked immunosorbent assay; S/P ratio Sample-to-positive ratio; rtPCR Real-time polymerase chain reaction; nd Not determined; NAC No amplification curve

in accordance. The Western blot analysis showed a band of approximately $150 \mathrm{kDa}$ in the otter's serum as well as in the canine serum, corresponding to the molecular weight of the IgG [14]. These findings support that the TR-IFMA using sheep anti-dog IgG2 is able to detect the IgG2 of otters. These results are in line with those of a previous study in which an indirect enzyme-linked immunoassay using anti-dog IgG detected the IgG of seven marine mammals including sea otters (Enhydra lutris) [15].

At the time of diagnosis, the otter presented bilateral epistaxis, anorexia, and apathy, all of which are clinical signs compatible with CanL [1]. The main changes detected in the analytical profile of the Leishmania-positive Eurasian otter were also in accordance with those reported in CanL: hyperproteinemia, hyperglobulinemia, decreases of PON-1, increases of haptoglobin and ferritin, and proteinuria $[1,16]$. After treatment, the general health condition of the animal improved, as it did not show any epistaxis, and the ferritin concentration decreased, as reported in CanL [16].

Natural infection by $L$. infantum in wildlife species in South-Eastern Spain was described in captive wolves and brown bears, and in free-ranging wildlife species such as foxes, rabbits and rodents $[17,18]$. In addition, Muñoz et al. [2] reported sand fly vector abundance in the 'Terra Natura' wildlife park. Based on our findings, we could hypothesize that Eurasian otters may act as a secondary reservoir for L. infantum infection in the Mediterranean basin. Infection in wildlife carnivores suggests that a sylvatic cycle of this pathogen may occur, being of particular importance to human and pet health [4]. 


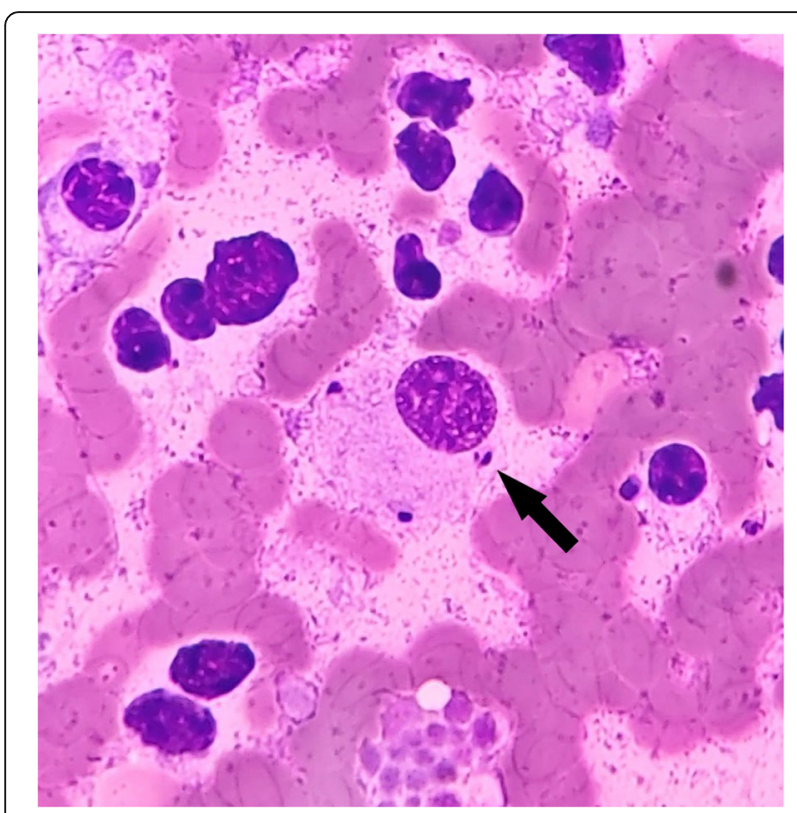

Fig. 3 Cytology of spleen of the sick Eurasian otter obtained by fineneedle aspiration. Oval microorganisms with eccentric nucleus compatible with Leishmania spp. amastigotes are found into the cytoplasm of macrophages. Note the eccentric nucleus and the kinetoplast of this microorganism (arrow). The slide has been stained with Diff-quick stain and observed at $\times 100$

A case of clinical leishmaniosis was, for the first time to the best of our knowledge, detected in a captive Eurasian otter. Therefore, the susceptibility of Eurasian otters to $L$. infantum infection and the development of clinical leishmaniosis in endemic areas should be considered.

\section{Supplementary information}

Supplementary information accompanies this paper at https://doi.org/10. 1186/s12917-020-02509-X

\begin{abstract}
Additional file 1. The original Western blot analysis image for Fig. 2. The target protein analyzed by Western blot was $\operatorname{lgG} 2$ in the serum of dogs and otters at dilutions 1:1000 (lines 1-4) and 1:2000 (lines 5-8). Lines 1 and 5: serum from the Leishmania-seropositive dog. Lines 2 and 6: serum from the Leishmania-seronegative dog. Lines 3 and 7: serum from the Leishmania-seropositive otter. Lines 4 and 8: serum from the Leishmania-seronegative otter. A sheep polyclonal antibody anti-dog lgG2 was used. A band of approximately $150 \mathrm{kDa}$ was observed in the canine sera as well as in the Leishmania-seropositive otter serum. MW, molecular weight marker (kDa) (Amersham ECL Rainbow Marker, GE Healthcare Bio-Sciences AB, Sweden).
\end{abstract}

\section{Abbreviations}

PON-1: Paraoxonase-1; EDTA: Ethylenediaminetetraacetic acid; CBC: Complete blood cell count; UFL: Units of fluorometry for Leishmania; ELISA: Enzymelinked immunosorbent assay; S/P: Sample-to-positive; OD: Optical density; rtPCR: Real-time polymerase chain reaction; BP: Biochemical profile; CRP: Creactive protein; TR-IFMA: Time-resolved immunofluorometric assay; nd: Not determined; NAC: No amplification curve

\section{Acknowledgements}

The authors would like to express their gratitude to Mrs. Sandra V. Mateo (Interlab-UMU, University of Murcia, Spain) for her expert assistance with the Western blot.

\section{Authors' contributions}

RN and EO performed the clinical evaluation, the echographical study, collected the samples and administered the treatment. LPM was involved in the hematological and biochemical analysis. ACB performed the serology and rtPCR analyses. ACB, SMS, JJC, FT and DE were involved in the data interpretation. ACB drafted the manuscript and SMS, JJC, FT and DE critically read and edited the manuscript. All authors read and approved the final manuscript.

\section{Funding}

The Interlab-UMU research group was funded by grant 19894/GERM/15 from the Seneca Foundation-Regional Agency for Science and Technology of the Region of Murcia, Spain. ACB was supported by the Seneca FoundationRegional Agency for Science and Technology of the Region of Murcia, Spain and the European Social Fund (21327/PDGI/19). DE was supported by a Juan de la Cierva postdoctoral fellowship from the Spanish Ministry of Economy, Industry and Competitiveness (IJC2018-035105-I). The funders had no role in study design, data collection and analysis, and decision to publish or preparation of the manuscript. These funders only provide economic support.

\section{Availability of data and materials}

All data generated or analysed during this study are included in this published article.

\section{Ethics approval and consent to participate}

This study did not require the approval of an ethical committee since it is a case report and samples used were surplus material from the diagnostic tests.

\section{Consent for publication}

The owner of the 'Terra Natura' wildlife park gave written consent for details of the examination of their animals and of their clinical details, together with any identifying images, to be published in this study.

\section{Competing interests}

The authors declare that they have no competing interests.

\section{Author details}

${ }^{1}$ Department of Animal Health, Regional Campus of International Excellence "Campus Mare Nostrum", University of Murcia, 30100 Espinardo, Murcia, Spain. ${ }^{2}$ Interdisciplinary Laboratory of Clinical Analysis, Interlab-UMU, Regional Campus of International Excellence "Campus Mare Nostrum", University of Murcia, 30100 Espinardo, Murcia, Spain. ${ }^{3}$ Parque Zoológico Terra Natura, 30100 Espinardo, Murcia, Spain. ${ }^{4}$ Department of Animal Production, Regional Campus of International Excellence "Campus Mare Nostrum", University of Murcia, 30100 Espinardo, Murcia, Spain.

Received: 4 March 2020 Accepted: 4 August 2020 Published online: 27 August 2020

\section{References}

1. Solano-Gallego L, Miró G, Koutinas A, Cardoso L, Pennisi MG, Ferrer L, Bourdeau P, Oliva G, Baneth G. The LeishVet group, LeishVet guidelines for the practical management of canine leishmaniosis. Parasit Vectors. 2011;4: 86. https://doi.org/10.1186/1756-3305-4-86.

2. Muñoz C, Martínez J, Puente D, Figuerola J, Cutillas PP, Navarro R, Ortuño M, Bernal LJ, Ortiz J, Soriguer R, Berriatua E. Molecular xenomonitoring and host identification of Leishmania sand fly vectors in a Mediterranean periurban wildlife park; 2019. p. 1-16. https://doi.org/10.1111/tbed.13319.

3. Giner J, Basurco A, Alcover MM, Riera C, Fisa R, López RA, Juan-sallés C. First report on natural infection with Leishmania infantum in a domestic ferret (Mustela putorius furo) in Spain. Vet Parasitol Reg Stud Reports. 2020;19: 100369. https://doi.org/10.1016/j.vprsr.2020.100369.

4. Battisti E, Zanet S, Khalili S, Trisciuoglio A, Hertel B. Molecular survey on vector-borne pathogens in Alpine wild Carnivorans. Front Vet Sci. 2020;7:19. https://doi.org/10.3389/fvets.2020.00001. 
5. Oleaga A, Zanet S, Espí A, Raquel M, De Macedo P, Gortázar C, Ferroglio E. Veterinary parasitology Leishmania in wolves in northern Spain : a spreading zoonosis evidenced by wild life sanitary surveillance. Vet Parasitol. 2018;255:26-31. https://doi.org/10.1016/j.vetpar.2018.03.015.

6. Cantos-Barreda A, Escribano D, Bernal LJ, Pardo-Marín L, Cerón JJ, MartínezSubiela S. New wide dynamic range assays for quantification of antiLeishmania IgG2 and IgA antibodies in canine serum. Vet Immunol Immunopathol. 2017;189:11-6. https://doi.org/10.1016/j.vetimm.2017.05.007.

7. Francino O, Altet L, Sánchez-Robert E, Rodriguez A, Solano-Gallego L, Alberola J, Ferrer $L$, Sánchez A, Roura X. Advantages of real-time PCR assay for diagnosis and monitoring of canine leishmaniosis. Vet Parasitol. 2006; 137:214-21. https://doi.org/10.1016/j.vetpar.2006.01.011.

8. Fernández-Morán J, Molina L, Flamme G, Saavedra D, Manteca-Vilanova X. Hematological and biochemical reference intervals for wild caught Eurasian otter from Spain. J Wildl Dis. 2001;37:159-63. https://doi.org/10.7589/00903558-37.1.159

9. Santoro M, Alessio ND, Cerrone A, Lucibelli MG, Borriello G, Aloise G, Auriemma C, Riccone N, Galiero G. The Eurasian otter ( Lutra lutra ) as a potential host for rickettsial pathogens in southern Italy. PLoS One. 2017:311. https://doi.org/10.1371/journal.pone.0173556.

10. Chadwick EA, Cable J, Chinchen A, Francis J, Guy E, Kean EF, Paul SC, Perkins SE, Sherrard-smith E, Wilkinson C, Forman DW. Seroprevalence of Toxoplasma gondii in the Eurasian otter (Lutra lutra) in England and Wales, Parasit. Vectors, vol. 6; 2013. https://doi.org/10.1186/1756-3305-6-75.

11. Malatesta D, Simpson VR, Fusillo R, Marcelli M, Bongiovanni L, Romanucci M, Palmieri C, Della Salda L. First description of adiaspiromycosis in an Eurasian otter (Lutra lutra) in Italy. Vet Ital. 2014;50:199-202. https://doi.org/10.12834/ Vetlt.40.1916.8.

12. Solano-Gallego L, Riera C, Roura X, Iniesta L, Gallego M, Valladares JE, Fisa R, Castillejo S, Alberola J, Ferrer L, Arboix M, Portús M. Leishmania infantumspecific $\lg G, \lg G 1$ and $\lg G 2$ antibody responses in healthy and ill dogs from endemic areas: evolution in the course of infection and after treatment. Vet Parasitol. 2001;96:265-76. https://doi.org/10.1016/S0304-4017(00)00446-5.

13. Chaabouni A, Boubaker R, Mhadhbi M, Gharbi M, Sassi A. Comparative analysis of the Leishmania infantum-specific antibody repertoires and the autoantibody repertoires between asymptomatic and symptomatic dogs. Vet Parasitol. 2018:261:9-17. https://doi.org/10.1016/j.vetpar.2018.07.011.

14. Valedkarimi Z, Nasiri H, Aghebati-maleki L, Abdolalizadeh J. Production and characterization of anti-human lgG F (ab') 2 antibody fragment. Hum Antibodies. 2018;26:171-6. https://doi.org/10.3233/HAB-180336.

15. Roehl K, Jankowski M, Hofmeister E. Antidog lgG secondary antibody successfully detects lgG in a variety of aquatic mammals. J Zoo Wildl Med. 2016;47:970-6

16. Cantos-Barreda A, Escribano D, Cerón JJ, Tecles F, Bernal LJ, Martínez-subiela S. Changes in the concentration of anti-Leishmania antibodies in saliva of dogs with clinical leishmaniosis after short-term treatment. Vet Parasitol. 2018;254:135-41. https://doi.org/10.1016/j.vetpar.2018.03.014.

17. Ortuño M, Latrofa MS, Iborra MA, Pérez P, Bernal L, Risueño J, Muñoz C Bernal A, Sánchez PF, Manuel L, Giada S, Carla A, Cortes S, Campino L, Otranto D, Berriatua E. Genetic diversity and phylogenetic relationships between Leishmania infantum from dogs, humans and wildlife in south east Spain; 2019. p. 1-13. https://doi.org/10.1111/zph.12646.

18. Risueño J, Ortuño M, Pérez-cutillas P, Goyena E, Maia C, Cortes S, Campino L, Bernal L, Muñoz C, Arcenillas I, Martínez-rondán FJ, Gonzálvez M, Collantes F. Epidemiological and genetic studies suggest a common Leishmania infantum transmission cycle in wildlife, dogs and humans associated to vector abundance in Southeast Spain, vol. 259; 2018. p. 61-7. https://doi.org/10.1016/j.vetpar.2018.05.012.

\section{Publisher's Note}

Springer Nature remains neutral with regard to jurisdictional claims in published maps and institutional affiliations.

Ready to submit your research? Choose BMC and benefit from:

- fast, convenient online submission

- thorough peer review by experienced researchers in your field

- rapid publication on acceptance

- support for research data, including large and complex data types

- gold Open Access which fosters wider collaboration and increased citations

- maximum visibility for your research: over $100 \mathrm{M}$ website views per year

At BMC, research is always in progress.

Learn more biomedcentral.com/submissions 